\title{
Pengaruh Penerapan Model Pembelajaran Inkuiri Terbimbing dengan Praktikum Konversi Energi Panas Ke Listrik untuk Meningkatkan Kemampuan Berpikir Kritis
}

\author{
${ }^{1}$ Anisa Apriyani Putri, ${ }^{2}$ Eko Suyanto, ${ }^{3}$ B. Anggit Wicaksono \\ 1,2 Program Studi Pendidikan Fisika, PMIPA, Universitas Lampung, J1. Prof. Dr.
} Sumantri Brojonegoro No. 1 Bandar Lampung, 35145, Indonesia. Email:anisaapriani999@gmail.com

\begin{tabular}{|c|c|}
\hline & Abstract \\
\hline & \multirow{2}{*}{$\begin{array}{l}\text { This study aims to determine the effect of the application of guided inquiry } \\
\text { learning models with the practice of converting heat to electricity to improve } \\
\text { critical thinking skills. The population of this research is all students of class XII } \\
\text { Science of SMA Negeri } 1 \text { Way Jepara. The selection of research samples using } \\
\text { purposive sampling techniques with a sample of class XII Science } 5 \text { totaling } 33 \\
\text { students. The research design used was One Group Pretest-Posttest. Learning is } \\
\text { done by conducting practicum activities using a set of guided inquiry-based heat } \\
\text { energy conversion devices. The tool used in practicum activities is an advantage } \\
\text { in this study because there has been no previous research that uses practicum } \\
\text { learning methods with tools to convert heat energy to electricity. Practicum } \\
\text { activities carried out on two learning topics or practicum twice. In practicum } \\
\text { activities topic one is about the unit thermoelectric generator module } \\
\text { specifications and in practicum activity topic two is regarding the thermoelectric } \\
\text { generator circuit to turn on the LED lights. Data were tested by N-gain analysis, } \\
\text { normality test, Paired Sample T-Test. Based on the results of the Paired Sample } \\
\text { T-test, it can be seen that the significance value of } 0.00 \text { is less than 0.05, it can } \\
\text { be concluded that there is an influence of students critical thinking skills before } \\
\text { and after using guided inquiry learning models with energy conversion }\end{array}$} \\
\hline & \\
\hline Informasi Artikel & \multirow{3}{*}{$\begin{array}{l}\text { Abstrak } \\
\text { Penelitian ini bertujuan untuk mengetahui pengaruh penerapan model } \\
\text { pembelajaran inkuiri terbimbing dengan praktikum konversi energi panas ke } \\
\text { listrik untuk meningkatkan kemampuan berpikir kritis. Populasi dari penelitian } \\
\text { ini yaitu seluruh siswa kelas XII IPA SMA Negeri } 1 \text { Way Jepara. Pemilihan } \\
\text { sample penelitian menggunakan teknik purposive sampling dengan sampel } \\
\text { kelas XII IPA } 5 \text { berjumlah } 33 \text { siswa. Desain penelitian yang digunakan adalah } \\
\text { One Group Pretest-Posttest. Pembelajaran dilakukan dengan melakukan } \\
\text { kegiatan praktikum menggunakan seperangkat alat konversi energi panas } \\
\text { berbasis inkuiri terbimbing. Alat yang digunakan pada kegiatan praktikum } \\
\text { menjadi keunggulan dalam penelitian ini karena belum ada penelitian } \\
\text { sebelumnya yang menggunakan metode pembelajaran praktikum dengan alat } \\
\text { konversi energi panas ke listrik. Kegiatan praktikum dilakukan pada dua topik } \\
\text { pembelajaran atau sebanyak dua kali praktikum. Pada kegiatan praktikum topik } \\
\text { satu mengenai spesifikasi satuan modul thermoelectric generator dan pada } \\
\text { kegiatan praktikum topik dua mengenai rangkaian thermoelectric generator } \\
\text { untuk menyalakan lampu LED. Data diuji dengan analisis N-gain, uji } \\
\text { normalitas, uji Paired Sample T-Test. Berdasarkan hasil uji Paired Sample T- } \\
\text { test dapat diketahui bahwa nilai signifikasi sebesar 0,00 yaitu kurang dari 0,05 } \\
\text { maka dapat disimpulkan bahwa terdapat pengaruh kemampuan berpikir kritis } \\
\text { siswa sebelum dan sesudah menggunakan model pembelajaran inkuiri }\end{array}$} \\
\hline & \\
\hline & \\
\hline \multicolumn{2}{|c|}{$\begin{array}{l}\text { tasi: Putri, A. A., Suyanto, E., Wicaksono, B. A. (2020). Pengaruh Penerapan Model Pembelajaran } \\
\text { kuiri Terbimbing dengan Praktikum Konversi Energi Panas Ke Lisrik untuk Meningkatkan Kemampuan } \\
\text { erpikir Kritis. Kappa Journal, 4(2), 127- 135. }\end{array}$} \\
\hline
\end{tabular}




\section{PENDAHULUAN}

Fisika merupakan salah satu cabang dari ilmu pengetahuan alam yang dipelajari di sekolah. Pada pembelajaran fisika di sekolah mengkaji perilaku, struktur dan interaksi benda secara empirik. Pembelajaran fisika seharusnya dimulai dengan pengamatan yang melibatkan fenomena dan gejala alam yang berkaitan dengan materi fisika yang akan diajarkan. Pada pembelajaran fisika kelas XII terdapat pokok bahasan sumber energi yang di dalamnya memuat materi mengenai energi terbarukan, contoh energi terbarukan, serta menganalisis sumber-sumber energi terbarukan dan dampaknya bagi kehidupan. Berdasarkan hasil observasi guru dan siswa kelas XII IPA di SMAN 1 Way Jepara, pembelajaran sumber energi belum menganalisis sumber-sumber energi terbarukan secara rinci. Pembelajaran yang dilakukan oleh guru masih menggunakan kajian teoritis karena belum dilakukan praktikum yang mendukung konsep dari sumber energi terbarukan.

Materi konversi energi panas menjadi energi listrik merupakan salah satu solusi keterbatasan sumber energi listrik. Pembelajaran ini diperlukan untuk memperkaya pengetahuan siswa mengenai sumber energi listrik selain energi kimia, nuklir, dan matahari. Dengan memahami materi tersebut siswa mempunyai peluang yang lebih besar dalam mencari sumber energi alternatif Berdasarkan Permendikbud No 24 Tahun 2016 Tentang Kompetensi Inti dan Kompetensi Dasar pada kurikulum 2013, kompetensi inti terdiri atas kompetensi inti sikap spiritual, sikap sosial, pengetahuan, dan keterampilan. Pada kurikulum 2013 edisi revisi diharapkan dapat diimplementasikan pembelajaran abad 21, hal ini untuk menyikapi tuntutan zaman yang semakin kompetitif. Adapun pembelajaran abad 21 mencerminkan empat hal yaitu kemampuan berpikir kritis, kreativitas, komunikasi, dan kolaborasi (Nichols dan Jennifer, 2017).

Pada kenyataannya masih ada pembelajaran fisika yang dilakukan dengan cara tekstual, dengan meminta siswa menghafal rumus-rumus. Hal ini menyebabkan tugas siswa menjadi lebih berat karena menitikberatkan pada konsep dan mengesampingkan fakta. Akibatnya siswa kehilangan kesempatan untuk memperoleh pengalaman belajar secara empirik, dan pembelajaran fisika menjadi kurang menarik. Salah satu strategi belajar yang dapat memberikan pengalaman empirik kepada siswa dalam belajar fisika adalah dengan metode praktikum. Peralatan praktikum untuk kepentingan pembelajaran fisika tersedia dalam bentuk Kotak Instrumentasi Terpadu (KIT). Pada kenyataanya KIT yang lengkap tidak dimiliki oleh setiap sekolah, terutama untuk sekolah-sekolah yang terletak di daerah. Thermoelectric generator atau TEG dapat digunakan sebagai solusi permasalahan tidak adanya peralatan praktikum pembelajaran fisika pada materi konversi energi panas. Adanya praktikum konversi energi menggunakan TEG tersebut, diharapkan dapat meningkatkan kemampuan berpikir kritis siswa.

Tujuan penelitian ini adalah melihat pengaruh penerapan model pembelajaran inkuiri terbimbing dengan menggunakan praktikum koversi energi panas terhadap peningkatan kemampuan berpikir kritis. Beberapa hasil penelitian yang relavan dengan model pembelajaran inkuiri, menyatakan bahwa model pembelajaran inkuiri dapat mengakibatkan prestasi siswa yang lebih tinggi dibandingkan metode pengajaran reguler dan dapat menyebabkan kemahiran yang lebih besar dalam sains (Njoroge, Changeiywo, \& Ndirangu, 2014). Pembelajaran praktikum berbasis inkuiri dapat meningkatkan keterampilan berpikir kritis siswa (Sundari, Pursitasari, \& Heliawati, 2017). Hasil belajar siswa dengan menerapkan model pembelajaran inkuiri terbimbing dengan melatihkan keterampilan proses sains dapat meningkatkan hasil belajar (Wahyudi \& Supardi, 2013). Pembelajaran inkuiri terbimbing melalui laboratorium virtual dan labolatorium riil berpengaruh secara signifikan terhadap prestasi belajar kognitif (Nugroho, Suparmi, \& Sarwanto, 2012). Penelitian ini dimulai dari melakukan analisis kebutuhan, dilanjutkan dengan identifikasi sumber daya untuk memenuhi kebutuhan produk, kemudian mengidentifikasi spesifikasi produk yang dibuat dan pengembangan produk dilanjutkan dengan praktikum penggunaan produk yang dilakukan oleh siswa. 


\section{METODE}

Desain eksperimen yang digunakan dalam penelitian ini adalah one group pretestposttest. Penelitian ini terdiri atas beberapa tahapan, yakni ((a) memilih atau menentukan masalah yang akan diteliti; (b) melakukan survey untuk mengamati langsung lokasi penelitian; (c) menentukan judul dan objek penelitian; (d) membuat analisis kebutuhan (e) merumuskan hipotesis terhadap masalah yang sedang diteliti; (f) membuat instrumen penelitian; (g) melakukan analisis instrument penelitian dengan cara uji validitas dan uji reabilitas; (h) observasi meminta izin kepada Kepala sekolah untuk melaksanakan penelitian dan menentukan sampel beserta waktu penelitian; (i) melaksanakan penelitian; (j) mengumpulkan data penelitian yang berkaitan dengan hasil pembelajaran peserta didik; (k) menganalisis data yang diperoleh; (1) menarik kesimpulan.

Subjek penelitian adalah kelas XII IPA SMA Negeri 1 Way Jepara Tahun Pelajaran 2019/ 2020 berjumlah 33 peserta didik. Data yang dikumpulkan dalam penelitian meliputi hasil belajar pretest dan posttest peserta didik. Data yang diperoleh kemudian dianalisis menggunakan skor gain yang ternormalisasi. N-gain digunakan untuk melihat perbedaan nilai pretest dan posttest siswa kelas XII IPA 5. N-gain diperoleh dengan menggunakan rumus :

$N-\operatorname{gain}(g)=\frac{S_{\text {post }}-S_{\text {pre }}}{S_{\text {max }}-S_{\text {pre }}}$

Keterangan:

$g \quad=N$-gain

$S_{\text {post }}=$ Skor posttest

$S_{\text {pre }} \quad=$ Skor pretest

$S_{\max }=$ Skor maksimum

Tabel 1. Kriteria $N$-gain

\begin{tabular}{lc}
\hline$N$-gain & Kriteria Berpikir Kritis \\
\hline$N$-gain $>0,7$ & Tinggi \\
$0,3 \leq N$-gain $\leq$ & Sedang \\
0,7 & \\
$N$-gain $<0,3$ & Rendah \\
\hline
\end{tabular}

(Hake, 2002)

Data hasil belajar peserta didik yang diperoleh kemudian dianalisis dengan melakukan uji normalitas dan uji hipotesis. Pengujian hipotesis menggunakan Paired Sample T-Test (Statistik Parametrik). Tujuannya untuk melihat perbedaan rata-rata hasil kemampuan berpikir kritis siswa sebelum diberi perlakuan (pretest) dan sesudah diberi perlakuan (posttest).

Adapun hipotesis yang akan diuji adalah:

$\mathrm{H}_{0}$ : Tidak ada perbedaan rata-rata kemampuan berpikir kritis sebelum dan sesudah pembelajaran

$\mathrm{H}_{1}$ : Ada perbedaan rata-rata kemampuan berpikir kritis siswa sebelum dan sesudah pembelajaran

Pengambilan keputusan berdasarkan nilai signifikansi:

Jika nilai Sig. atau signifikansi $>0,05$ maka $\mathrm{H}_{0}$ diterima;

Jika nilai Sig. atau signifikansi $<0,05$ maka $\mathrm{H}_{0}$ ditolak 
Instrumen pengumpulan data yang digunakan adalah tes essay, sedangkan data hasil belajar yang diperoleh dapat ditentukan dengan menggunakan rumus :

Nilai Total Akhir (NT) $=\frac{\text { Nilai yang diperoleh siswa }(\text { NA) }}{\text { Nilai maksimal siswa }(N S)} \times 100 \%$

\section{HASIL DAN PEMBAHASAN}

\section{Hasil}

Analisis data hasil belajar peserta didik disajikan pada tabel berikut.

Tabel 2. Data Rata-Rata Hasil Pretest dan Posttest Siswa

\begin{tabular}{lcc}
\hline Parameter & Pretest & Posttest \\
\hline Jumlah Siswa & 33 & 33 \\
Nilai Terendah & 35 & 62,5 \\
Nilai Tertinggi & 55 & 85 \\
Nilai Maksimum & 100 & 100 \\
Rata-rata Nilai & 44,64 & 74,93 \\
\hline
\end{tabular}

Berdasarkan rata-rata nilai pretest dan posttest menyatakan bahwa kemampuan berpikir kritis siswa meningkat.

Berikut merupakan perolehan rata-rata $\mathrm{N}$-Gain kemampuan berpikir kritis siswa ditampilkan pada Tabel 3.

Tabel 3. Rata-rata $N$-Gain kemampuan berpikir kritis

\begin{tabular}{llll}
\hline $\begin{array}{l}\text { Gain } \\
\text { Tertingg }\end{array}$ & $\begin{array}{l}\text { Gain } \\
\text { Terendah }\end{array}$ & $\begin{array}{l}\text { Rata- } \\
\text { N-Gain }\end{array}$ & kategori \\
\hline 92,59 & 59,26 & 0,75 & Tinggi
\end{tabular}

Skor rata-rata kemampuan berpikir kritis siswa memperoleh rata-rata N-Gain 0,75 yang menunjukkan dalam kategori tinggi.

Hasil uji normalitas data pretest dan posttest siswa dapat dilihat pada Tabel 4 sebagai berikut:

Tabel 4. Hasil uji normalitas kemampuan berpikir kritis

\begin{tabular}{llcc}
\hline Aspek & Sig & Berdistribusi Normal & Tidak Berdistribusi Normal \\
\hline Pretest & 0,058 & $\checkmark$ & \\
\hline Postest & 0,200 & $\checkmark$ & \\
\hline
\end{tabular}

Berdasarkan Tabel 4, diketahui bahwa data nilai pretest dan posttest siswa berdistribusi normal, di mana nilai sig lebih dari 0,05 yaitu 0,058 dan 0,200. 
Tabel 5. Hasil Paired Sample T-Test Kemampuan Berpikir Kritis

\begin{tabular}{cccc}
\hline Pair & $t$ & $d f$ & Sig. (2-tailed) \\
\hline Pretest- Posttest & $-43,157$ & 32 & 0,00 \\
\hline
\end{tabular}

Berdasarkan Tabel 5 dapat diketahui bahwa nilai signifikasi sebesar 0,00 yaitu kurang dari 0,05 maka dapat disimpulkan bahwa terdapat perbedaan yang signifikan kemampuan berpikir kritis siswa sebelum dan sesudah menggunakan model pembelajaran inkuiri terbimbing dengan praktikum konversi energi panas ke listrik.

Berikut data rata-rata kemampuan berpikir kritis pada setiap indikator yang ditampilkan pada tabel 6.

Tabel 6. Rata-rata Kemampuan Berpikir Kritis pada setiap Indikator

\begin{tabular}{llccc}
\hline & Indikator Kemampuan Berpikir & \multicolumn{2}{c}{ Rata-rata } & \\
\cline { 3 - 4 } No & \multicolumn{1}{c}{ Kritis } & Pretest & Posttest & Peningkatan (\%) \\
\hline 1 & Memberikan penjelasan sederhana & 62 & 104 & $68 \%$ \\
2 & Membangun keterampilan dasar & 52 & 87 & $67 \%$ \\
3 & Menyimpulkan & 62 & 103 & $66 \%$ \\
4 & Memberikan penjelasan lanjut & 57 & 96,5 & $69 \%$ \\
5 & Memberikan strategi dan taktik & 61,5 & 104,5 & $70 \%$ \\
\hline
\end{tabular}

Peningkatan kemampuan berpikir kritis tertinggi yaitu pada memberikan strategi dan taktik yaitu sebesar $70 \%$.

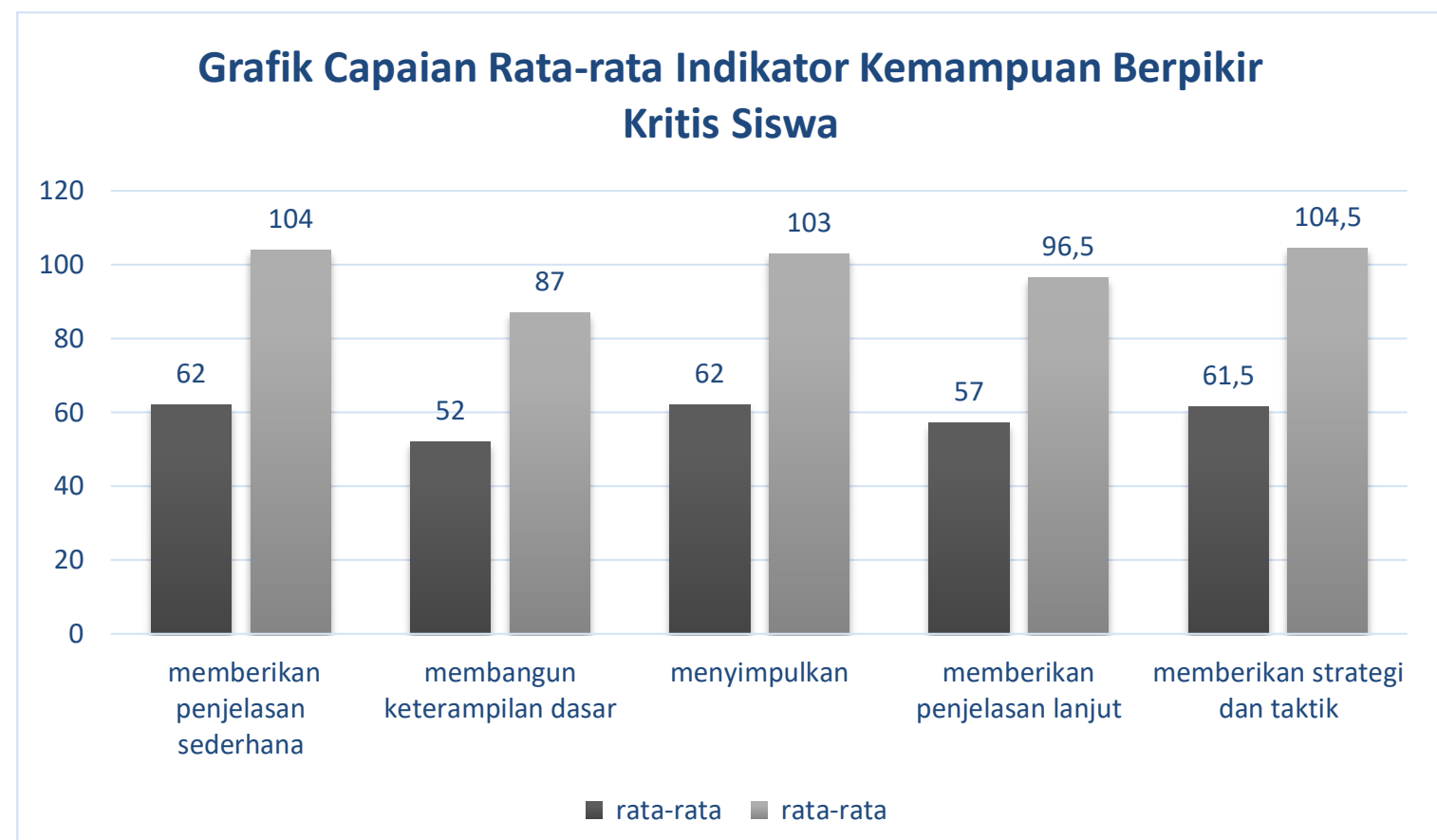

Gambar 1. Grafik Capaian Rata-rata Indikator Keterampilan Berpikir Berdasarkan Hasil Pretest dan Posttest

Berdasarkan gambar 1 menunjukkan grafik peningkatan kemampuan berpikir kritis peserta didik berdasarkan nilai pretest dan posttesst. Peningkatan indikator tertinggi yaitu pada indikator memberikan strategi dan taktik. 


\section{Pembahasan}

Penelitian ini dilakukan untuk melihat pengaruh penerapan model pembelajaran inkuiri terbimbing dengan praktikum konversi energi panas ke listrik terhadap peningkatan kemampuan berpikir kritis siswa. Penelitian ini dilakukan dengan cara memberikan soal pretest dan posttest untuk mengukur kemampuan berpikir kritis. Pemberian soal pretest dilakukan untuk mengukur keterampilan awal siswa sebelum diberikan perlakuan pembelajaran dan pemberian soal posttest dilakukan untuk mengukur peningkatan kemampuan akhir siswa. Penelitian ini menggunakan model pembelajaran inkuiri terbimbing untuk meningkatkan kemampuan berpikir kritis siwa. kemampuan berpikir kritis yang digunakan dalam penelitian ini mengacu pada kemampuan berpikir kritis menurut Ennis, yang meliputi memberikan penjelasan, membangun keterampilan dasar, menyimpulkan, memberikan penjelasan lanjut, dan menentukan strategi dan taktik.

Hasil uji hipotesis menggunakan menggunakan teknik Paired Sample T-test, memiliki nilai asymp sig. (2-tailed) sebesar 0,00 yaitu kurang dari 0,05 maka dapat disimpulkan bahwa terdapat perbedaan yang signifikan kemampuan berpikir kritis siswa sebelum dan sesudah menggunakan model pembelajaran inkuiri terbimbing dengan praktikum konversi energi panas. Dilihat bahwa rata-rata pretest yang diperoleh oleh siswa sebelum diberikan perlakuan hanya sebesar 44,64. Berdasarkan hasil yang diperoleh tersebut keterampilan awal yang dimiliki siswa sebelum diberikan perlakuan dapat dikatakan masih rendah, setelah diberikan perlakuan diperoleh hasil peningkatan kemampuan berpikir kritis yaitu sebesar 74,93. Peningkatan kemampuan berpikir kritis siswa dapat dilihat dari peningkatan setiap indikatornya pada saat diberikan soal pretest dan posttest. Peningkatan kemampuan berpikir kritis siswa pada setiap indikator saat diberikan soal pretest dan posttest dapat dilihat pada gambar 1. Peningkatan indikator tertinggi yaitu pada indikator memberikan strategi dan taktik. Peningkatan indikator ini disebabkan dalam pembelajaran dengan model pembelajaran inkuiri dengan praktikum konversi energi siswa diberikan kesempatan untuk berperan aktif dalam pembelajaran dengan memberikan sebuah praktikum dan mampu memberikan kesimpulan materi yang dipelajari.

Penggunaan model pembelajaran inkuiri terbimbing dengan praktikum konversi energi panas pada pembelajaran sumber energi dapat membantu siswa melakukan kegiatan penemuan. Setelah melalui aktivitas praktikum topik satu dan topik dua, siswa dapat mengetahui bahwa adanya perbedaan suhu dari proses konversi energi panas ke listrik menghasilkan arus dan tegangan yang dapat menyalakan lampu LED dan peralatan listrik lainnya apabila tegangan yang dihasilkan dari proses konversi energi tersebut sudah sesuai dengan tegangan yang dibutuhkan pada peralatan listrik yang akan dinyalakan. Setelah melakukan praktikum konversi energi panas dengan model pembelajaran inkuiri terbimbing, siswa dapat menemukan sendiri konsep- konsep dari konversi energi panas berdasarkan sajian data baik berupa tabel, skema proses perpindahan panas, maupun persamaan efek seeback. Melalui aktivitas penemuan secara langsung dan nyata tersebut, maka siswa akan memiliki pengalaman tersendiri dan ilmu yang dipelajarinya dapat bertahan lebih lama. Memperoleh pembelajaran secara langsung dan nyata diungkapan oleh Sagala (2005: 220) bahwa dengan melibatkan kegiatan tersebut dapat membuat siswa lebih percaya atas kebenaran berdasarkan praktikum yang dilakukan sendiri daripada hanya menerima penjelasan dari guru atau dari buku. Siswa belajar dengan mengalami atau mengamati sendiri suatu proses atau kejadian, sehingga hasil belajar siswa akan lebih bertahan lama.

Sejalan dengan penelitian Ependi (2016) bahwa berdasarkan hasil analisis diketahui bahwa belum ada materi konversi energi panas menjadi listrik secara rinci sehingga diperlukan perangkat yang dapat membantu siswa untuk mendalami perilaku perubahan panas menjadi listrik, kegiatan dilanjutkan dengan mencari solusi untuk masalah tersebut. sehingga mudah bagi siswa untuk melakukan analisis fenomena gerak tersebut. Pembelajaran menggunakan praktikum konversi energy panas memiliki tingkat pengalaman 
belajar yang tinggi. Selain melibatkan kegiatan praktikum secara langsung yang berada pada urutan pengalaman belajar yang paling tinggi, pembelajaran ini juga melibatkan kegiatan diskusi, serta menyajikan informasi. Banyak dan tingginya pengalaman belajar siswa ini akan meningkatkan daya mengingat siswa, sehingga akan meningkatkan pemahaman siswa. Pengalaman belajar menggunakan praktikum konversi energy panas akan lebih konkrit daripada penggunaan media verbal saja, seperti hanya membaca dan mendengar.

Adanya pengaruh pengalaman belajar terhadap daya ingat siswa dikemukan oleh Dale dalam Arsyad (2003) bahwa kerucut pengalaman dari yang bersifat langsung (konkrit), melalui benda tiruan, sampai pada lambang verbal (abstrak) tentunya memberikan implikasi tertentu terhadap hasil belajar siswa. Melalui pengalaman langsung siswa dapat mengingat materi maksimal 90\%, siswa diberi kesempatan melakukan sesuatu dapat mengingat $75 \%$, melalui metode diskusi siswa dapat mengingat 50\%, siswa diberikan kegiatan melihat video dan gambar dapat mengingat $30 \%$, dan siswa diberikan kegiatan membaca dan mendengar dapa mengingat $10 \%$. Kemampuan berpikir kritis siswa yang tinggi didukung kegiatan aktif siswa dalam proses pembelajaran. Kegiatan siswa berlangsung sangat padat mulai dari merumuskan masalah, melakukan praktikum secara langsung, menuliskan hasil praktikum, menganalisis data hasil praktikum, hingga mengomunikasikan hasil praktikum. Sehingga, siswa tidak dapat melakukan kegiatan lain yang bersifat non-edukatif. Siswa sangat tertarik dalam melakukan kegiatan pembelajaran karena mereka baru mengetahui dan menggunakan secara langsung alat untuk konversi energi. Hal ini dapat dilihat secara langsung dari aktifnya siswa dalam melakukan praktikum dan menganalisis data. Proses pembelajaran ini juga melibatkan beberapa alat indera sekaligus yang dapat membuat siswa lebih bersemangat lagi untuk mengikuti pembelajaran.

Sejalan dengan penelitian Yunita \& Wijayanti (2017) bahwa pemanfaatan teknologi dalam proses pembelajaran dapat menunjang dan membantu para guru dalam penyampaikan materi. Siswa tidak hanya menerima materi dari guru secara terpusat, tetapi siswa selalu aktif bertanya, aktif berdiskusi, dan mempresentasikan hasil kerjasama sehingga aktivitas siswa dalam mengikuti pembelajaran di kelas menjadi lebih aktif. Pembelajaran yang dimulai dengan memotivasi siswa secara ilmiah yakni memberikan contoh permasalahan dilingkungan sekitar yang sesuai dengan materi, dilanjutkan dengan melakukan praktikum. Adanya praktikum tersebut, juga melatih siswa untuk aktif dalam hal melakukan, mengamati, dan menginterpretasi hasil praktikum secara sistematis. Hal ini sesuai dengan pendapat Darwis (2015) bahwa model inkuiri terbimbing mengajak siswa untuk memaknai suatu proses ilmiah sebagai sesuatu yang harus dilaksanakan dengan sungguh-sungguh, dengan kemampuan yang benar-benar ditujukan untuk mengeksplorasi data, merumuskan dan menguji hipotesis, menghasilkan penemuan baru, dan menganalisis hasil penemuan yang orisinal dan kreatif. Menurut Sesen \& Tarhan (2013) bahwa pembelajaran berbasis inkuiri dengan aktivitas laboratorium merupakan suatu kombinasi yang efektif dalam kegiatan pembelajaran. Pembelajaran tersebut mampu memberikan kesempatan kepada siswa untuk aktif dalam berinteraksi, refleksi, dan berinisiatif pada kegiatan diskusi.

\section{KESIMPULAN}

Terdapat pengaruh model pembelajaran inkuiri terbimbing dengan praktikum konversi energi panas terhadap kemampuan berpikir kritis siswa secara signifikan. Praktikum konversi energi panas dengan model pembelajaran inkuiri terbimbing memiliki pengaruh yang signifikan terhadap kemampuan berpikir kritis siswa dapat dilihat dari peningkatan skor rata-rata kemampuan berpikir kritis dengan rata-rata $N$-Gain 0,75 yang menunjukkan dalam kategori tinggi. 


\section{SARAN}

Pembelajaran inkuiri terbimbing dengan praktikum konversi energi panas dapat dijadikan salah satu alternatif bagi guru di sekolah dalam upaya meningkatkan kemampuan berpikir kritis siswa serta pada penggunaan alat praktikum konversi energy panas ke listrik perlu diperhatikan penguasaan guru dengan baik dalam penggunaan alat tersebut agar proses pembelajaran lebih mudah dan dapat diterima siswa dengan baik.

\section{DAFTAR PUSTAKA}

Afandi, M., Chamalah, E., \& Puspita Wardani, O. (2013). Model \& Metode Pembelajaran di Sekolah. In Unissula Press.

Ahmatika, D. (2017). Peningkatan Kemampuan Berpikir Kritis Siswa Dengan Pendekatan Inquiry/Discovery. Euclid, 3(1), 394-403. https://doi.org/10.33603/e.v3i1.324

Andrapica, G., Mainil, R. I., \& Aziz, A. (2017). Pengujian Thermoelectric Generator Sebagai Pembangkit Listrik Dengan Sisi Dingin Menggunakan Air Bertemperatur $10{ }^{\circ} \mathrm{c}$. Jurnal Sains Dan Teknologi, 14(2), 45-50. Retrieved from https://ejournal.unri.ac.id/index.php/JST/article/ view/3983/3867

Arikunto, Suharsimi.2002. Metodologi Penelitian. Jakarta : PT. Rineka Cipta

Culp, \& W, A. (1996). Prinsip-Prinsip Konversi Energi. Jakarta: Erlangga.

Cohen, L., Manion, L., \& Morrison, K. 2007. Research Methods in Education (6th ed.). London and New York, NY: Routledge Falmer.Corlu., dkk. (2014). Introducing STEM Education : Implications for Educating Our Teacher for The Age of Innovation. Education and Science. 39: 171

Damayanti, I., \& Mintohari. (2014). Penerapan Model Pembelajaran Inkuiri untuk Meningkatkan Hasil Belajar Mata Pelajaran IPA Sekolah Dasar. Jurnal

Pendidikan, 1-12.

Diyastari, \& Annisa. (2015). Analisis Elektromotansi Termal antara Pasangan Logam Aluminium, Nikrom dan Platina sebagai Termokopel. Jurnal Pengajaran

Fisika., Vol 2(3),.

Ennis, R. H. \& Weir, E. 1985. The Ennis Weir Critical Thinking Essay Test, Pacific Grove, CA: Midwest Publication, I.

Faizal Al Farissy. (2013). Studi Eksperimental Termoelektrik Generator (Teg) Dengan Variasi Fin Dan Non Fin Pada Fluida Panas Supra X 125 Cc. Journal of Chemical Information and Modeling, 53(9), 1689-1699. https://doi.org/10.1017/CBO9781107415324.004 